\title{
Avascular necrosis of mandibular condyle: a case against extracorporeal fixation of condylar fracture
}

\author{
Kumar Nilesh
}

Oral \& Maxillofacial Surgery, Krishna Institute of Medical Sciences Deemed University, Karad, India

Correspondence to Dr Kumar Nilesh; drkumarnilesh@yahoo.com

Accepted 28 November 2020

Check for updates

(c) BMJ Publishing Group Limited 2020. No commercial re-use. See rights and permissions. Published by BMJ.

To cite: Nilesh K. BMJ Case Rep 2020;13:e239737. doi:10.1136/bcr-2020239737

\section{DESCRIPTION}

A 25 -year-old male patient was referred to maxillofacial surgery clinic for management of mandibular condyle fracture. The patient did not have any deleterious oral habit. The patient was systemically healthy and his routine laboratory examinations were within normal limits. The patients had limited mouth opening with deranged occlusion. CT revealed the right condyle out of the glenoid fossa and displaced anteromedially into the pterygomandibular space (figure 1A,B).

Although condylar fracture is common, its management has always been controversial, and vary from close reduction with intermaxillaryfixation to open reduction with internal fixation. ${ }^{1}$ Extracapsular or cranial displacement, presence of foreign body and failure of closed reduction warrant surgical intervention. ${ }^{2}$ Open reduction and internal fixation was planned for the present case, due to severe displacement of the condyle along with limited mouth opening and deranged occlusion. The patient was taken up for the planned procedure under general anaesthesia. The fracture site was approached by retromandibular incision. The distal end of the fracture condyle was located. However, there was failure to mobilise the condylar segment into the glenoid fossa due to severe medial displacement and the pull of lateral pterygoid muscle. Manual traction of the mandible inferiorly did not provide further medial access for fracture reduction.

High level and severely displaced condyle fracture can often be difficult to access and visualise intraoperatively. Pull from the lateral pterygoid muscle further makes fracture reduction and fixation difficult and unstable. Greater medial dissection also increases the risk of bleeding from the branches of internal maxillary artery. All these factors increase the surgical risk of damage to parotid gland and facial nerve. ${ }^{2}$ In such situation, detachment of the condylar segment and its extracorporeal fixation has been advocated in the literature for satisfactory anatomical alignment of fracture fragment. ${ }^{2-6}$ In the present case, due to the failure to adequately reduce the condylar segment, extracorporeal fixation was undertaken. After carefully dissecting the muscle and soft tissue attachments, the displaced condylar head was brought out of the surgical site and the fixation device accommodating two screws on either side of fracture was secured to it extracorporeally (figure 1C). The segment was placed back and secured with the native mandible to achieve anatomically acceptable reduction with the condyle in its normal position in the glenoid fossa (figure 1D). The adequacy of reduction and fixation was confirmed on the postoperative CT scan (figure 1E,F).

The postsurgical period was uneventful. The patient was kept on monthly follow-up visits. Postoperatively, the occlusion was stable. With active physiotherapy, the jaw movements returned to its normal range. However, at 14th month postoperatively, the patient reported pain over the right preauricular region with mild occlusal discrepancy. Imaging with posterior-anterior skull view showed loose fixation device with a screw displaced into the overlying soft tissue (figure 2A). Decision to explore the surgical site for removal of implants was taken after discussion with the patient. The previous incision was used to reenter the operated area and the loose screw was identified and removed. The remaining fixation device was loose and disengaged from the bone. On careful, inspection the condylar segment was rough and appeared necrosed, and was subsequently removed (figure $2 \mathrm{~B}$ ). The area was debrided with copious amount of antiseptic solution and normal saline, following which closure was done in layers. Postoperatively, the patient was kept on arch-bar with elastic traction, to guide the teeth into occlusion and prevent jaw deviation on opening (figure 2C). A temporomandibular reconstruction was advised in future, but in view of financial constraints and absence of any functional limitation the patient denied the same.

Use of extracorporeal fixation for condylar fracture has been sporadically reported in the English literature. Boyne described the technique of extracorporeal fixation in 35 cases of severely displaced condyle fracture, joint reconstruction

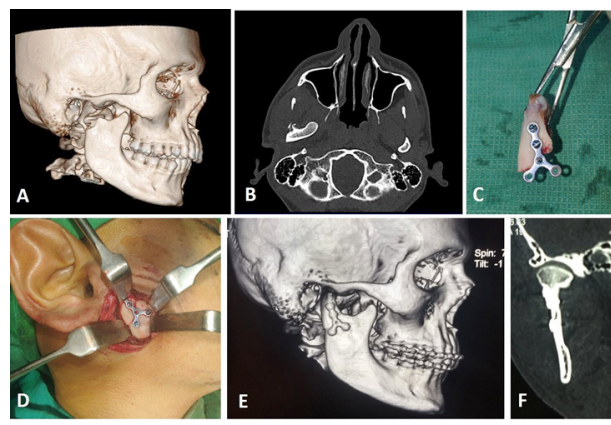

Figure 1 CT scan (A) three-dimensional (3D) image and (B) axial section showing displaced condyle fracture on right side. Intraoperative photographs showing (C) extracorporeal fixation of the condyle and (D) restoration of the joint anatomy. Postoperative CT scan (E) 3D image and $(\mathrm{F})$ coronal section showing accurate alignment of fracture segment. 


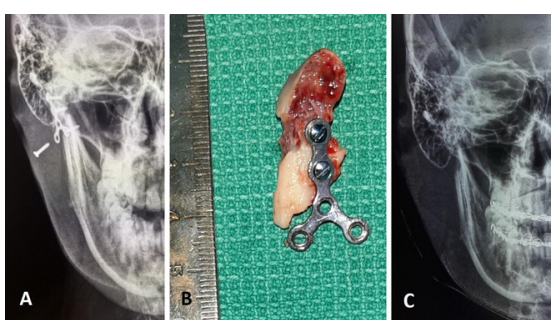

Figure 2 (A) Radiograph showing failure of hardware for fixation of fracture segment, (B) intraoperative image of necrosed condyle segment and $(C)$ postoperative radiograph after removal of necroed condyle.

after mandibular resection and for access osteotomy. The free transplantation did not cause any aseptic necrosis or arthritic changes over 3-15-year follow-up. ${ }^{5}$ Mikkonen et al advocated extracorporeal fixation combined with ramus osteotomy to improve access for management anteromedially displaced condylar head fracture. Nine patients treated with this technique showed complete restoration of joint function with no permanent complications at 32-month follow-up. However, radiographic evaluation revealed some deformation of the operated condyles. ${ }^{6}$ Gupta and Sahoo in 2009 conducted a study on extracorporeal fixation of 18 condylar fracture and experienced satisfactory occlusal stability and functional recovery. However, one patient $(6 \%)$ had complete resorption of condylar fragment, but recovery of occlusion and mandibular movement was satisfactory. ${ }^{4}$ Park et al reported higher rate of condylar resorption in $32 \%$ cases, within 9 months after extracorporeal fixation of 10 condylar fractures. ${ }^{2}$

Blood supply of condyle is primarily endosteal (from inferior alveolar artery) and periosteal (branches of internal maxillary artery). Facture of condyle disrupts the endosteal vessels, while the periosteal supply is severed both during trauma and periosteal stripping for open reduction and fixation. In extracorporeal fixation, the condyle segment is stripped from of the lateral pterygoid muscle, further reducing the vascular supply. When choosing extracorporeal fixation, it should be kept in mind the condyle is used as a free graft, and the possibility of resorption and avascular necrosis will always be there, as highlighted in the present case. Therefore, it should be undertaken only when the other options fail.

\section{Learning points}

- Condylar injuries are common, yet most controversial facial bone fracture in terms of the choice of treatment. While both closed and open methods of management are frequently used, it is widely accepted that severely displaced fracture with functional problems of pain, limited jaw movement and malocclusion should be treated by open reduction and internal fixation.

- Severely displaced condyle segment may be difficult to surgically access. Reduction of fracture to restore the anatomical continuity and normal joint anatomy may be further complicated by the strong pull of attached muscle. In such case the use of extracorporeal fixation has been adequately described and documented in the literature.

- The risk of condylar resorption after extracorporeal fixation reportedly vary from $5 \%$ to $30 \%$. The risk is almost negligible when in situ fixation is done. Hence, extracorporeal fixation should be the last resort in managing condylar fracture, due to associated risk of avascular necrosis.

Contributors KN was involved with patient care and manuscript drafting.

Funding The author has not declared a specific grant for this research from any funding agency in the public, commercial or not-for-profit sectors.

Competing interests None declared.

Patient consent for publication Obtained.

Provenance and peer review Not commissioned; externally peer reviewed.

\section{REFERENCES}

1 Hyde N, Manisali M, Aghabeigi B, et al. The role of open reduction and internal fixation in unilateral fractures of the mandibular condyle: a prospective study. Br J Oral Maxillofac Surg 2002;40:19-22.

2 Park SY, Im JH, Yoon SH, et al. A follow-up study on extracorporeal fixation of condylar fractures using vertical ramus osteotomy. J Korean Assoc Oral Maxillofac Surg 2014; $40: 76-82$.

3 Davis BR, Powell JE, Morrison AD. Free-grafting of mandibular condyle fractures: clinical outcomes in 10 consecutive patients. Int J Oral Maxillofac Surg 2005;34:871-6.

4 Gupta MV, Sahoo NK. Extracorporeal Fixation of Displaced Mandibular Condylar Fracture : Viable Option. Med J Armed Forces India 2009;65:229-31.

5 Boyne PJ. Free grafting of traumatically displaced or resected mandibular condyles. $J$ Oral Maxillofac Surg 1989;47:228-32.

6 Mikkonen P, Lindqvist C, Pihakari A, et al. Osteotomy-osteosynthesis in displaced condylar fractures. Int J Oral Maxillofac Surg 1989;18:267-70.

Copyright 2020 BMJ Publishing Group. All rights reserved. For permission to reuse any of this content visit

https://www.bmj.com/company/products-services/rights-and-licensing/permissions/

BMJ Case Report Fellows may re-use this article for personal use and teaching without any further permission.

Become a Fellow of BMJ Case Reports today and you can:

- Submit as many cases as you like

- Enjoy fast sympathetic peer review and rapid publication of accepted articles

- Access all the published articles

Re-use any of the published material for personal use and teaching without further permission

Customer Service

If you have any further queries about your subscription, please contact our customer services team on +44 (0) 2071111105 or via email at support@bmj.com.

Visit casereports.bmj.com for more articles like this and to become a Fellow 